Research article

\title{
Effect of fungal inoculants on growth and establishment of Gmelina arborea Roxb. in transplantation conditions
}

\author{
Manas Ranjan Panigrahi, Soumya Ranjan Nayak and Nibha Gupta* \\ Plant Pathology \& Microbiology Division, Regional Plant Resource Centre, Bhubaneswar-51015, Odisha, India \\ *Corresponding Author: nguc2003@yahoo.co.in \\ [Accepted: 16 April 2017]
}

\begin{abstract}
To evaluate the effect of fungal inoculants, a pot experiment was carried out on 30 days old transplanted seedlings of Gmelina arborea under nursery condition. Transplants were inoculated with seven day old liquid culture of Aspergillus ellipticus, Fusarium incarnatum, Aspergillus aculeatus, Aspergillus candidus, Penicillium species, Alternaria alternata, Penicillium species, Fusarium javanicum, Penicillium cyclopium, Aspergillus flavus separately. Growth of plants were measured in terms of plant height, leaf no, leaf size, biomass, NAR, RGR, LAR after 120 days. Data recorded on growth performance of Gmelina arborea plant exhibited the positive impact of fungal inoculation especially in case of Fusarium incarnatum, Penicillium species, Penicillium cyclopium and Aspergillus flavus over un-inoculated control. Successful establishment after transplantation and improvement in growth over control has been demonstrated well when plants were treated with Aspergillus flavus.
\end{abstract}

Keywords: Gmelina arborea - Phosphate solublization - Transplantation - Growth.

[Cite as: Panigrahi MR, Nayak SR \& Gupta N (2017) Effect of fungal inoculants on growth and establishment of Gmelina arborea Roxb. in transplantation conditions. Tropical Plant Research 4(1): 176-179]

\section{INTRODUCTION}

Filamentous fungi are widely used as production of organic acid and are capable of solubilising the insoluble form of phosphate, make them available to the plant root system indirectly (Manoharachary et al. 2005, Richa $e t$ al. 2007, Pandey et al. 2008, Yadav et al. 2011). It is important to note that sufficient and balanced quantities of nutrients needed for optimal growth of plants. Most of the nutritional contents in soil are present in bonded form and released only through biological and/or chemical activity. In such circumstances supplementation of chemical fertilizers is the only alternative to enrich the soil. But organic fertilizers are not the long term nutrient supplier (Pascual et al. 1997, Patil et al. 2002, Mehrvarz \& Chaichi 2008, Reis et al. 2008). In such cases, bioinoculation of mineral solubilisers have shown a vital role in growth and development of plants especially forest tree species (Pascual et al. 1997, Sahgal et al. 2004, Thatoi et al. 2005). The development of proper soil mixture for use in the nursery may be the cost effective process to attain better growth and production of tree species (Dash et al. 2013). Many such uses of biofertilizer for the production of quality planting material of forest trees are well reported (Barua et al. 2010, Dhar \& Mridha 2012). Gmelina arborea Roxb. is a large, tropical, evergreen perennial tree, an important medicinal plant and preferred in afforestation programs because of its unique timber (Orwa et al. 2009). It is reported that in poor soil, plantation of the tree may suffer from nutrient disorder (Sturmann et al. 1994). The importance of fungal inoculation in Gmelina arborea under heavy metal stress condition has also been reported (Barua et al. 2010). Under nutrient depletion condition, the inoculation of mineral solubilising fungi play a vital role in growth and establishment of forest tree seedlings. In view, an experiment under nursery condition has been carried out along with fungal inoculation in transplanted seedlings of $G$. arborea and growth performance was evaluated.

\section{MATERIALS AND METHODS}

The pot experiment was carried out in poly bags (size: $12 \times 16 \mathrm{~cm}$ containing $5.5 \mathrm{~kg}$ red laterite soil) received average $35 \pm 2^{\circ} \mathrm{C}$ temperature \& $60-80 \%$ relative humidity. The soil contains a high amount of iron, manganese 
and copper. Textural class of the soil was loamy sand the soil $\mathrm{pH}$ was 5.61. Average nitrogen (N), average phosphate $\left(\mathrm{P}_{2} \mathrm{O}_{5}\right)$ and average potassium $\left(\mathrm{K}_{2} \mathrm{O}\right)$ of the soil was $232.0 \mathrm{~kg} \cdot \mathrm{Ha}^{-1}, 25.2 \mathrm{~kg} \cdot \mathrm{Ha}^{-1}$ and $99.12 \mathrm{~kg} \cdot \mathrm{Ha}^{-1}$ respectively. The soil was fumigated with $1 \%$ formalin $(25 \mathrm{ml}$ per pot) for $48 \mathrm{hrs}$ prior to the experiment.

The seeds were collected from native plant and were treated with organic manure water for 72 hrs to depulp. After drying at room temperature, seeds were sown in experimental poly bags 1 inch below the upper surface. The seedlings were transplanted after 30 days from DAS (days of sowing) to other polypots of the similar capacity and filled with the same type of soil. Seven days after the transplantation, $25 \mathrm{ml}$ of 7 days old fungal culture (prepared in Czapek dox medium pH 4.5) of 10 different fungi were added separately in 20 replications to the polybags contain Gmelina arborea Roxb. seedlings. Fungal inoculations were repeated thrice in one month's interval of the experiment duration of 120 days. Observations after 4 months from DAS (date of sowing) were recorded for shoot height, a number of leaves, leaflets, branches, the fresh and dry biomass of leaves and stem (Leopold \& Kriedemann 1975). The data were evaluated for RGR (Relative growth rate), NAR (Net Assimilation Rate) and LAR (Leaf area ratio) and quality index (Dickson et al. 1960, Basak et al. 2004, Tewari et al. 2006).

\section{RESULT AND DISCUSSION}

Fungal inoculation exhibited the improved shoot height as compare to uninoculated control. Penicillium species and Aspergillus flavus both fungi had shown enhancement in shoot and root as well (Table 1). Treated and transplanted plants had developed 3-4 branches under fungal inoculation of Fusarium javanicum, Penicillium cyclopium and Fusarium incarnatum. The highest no of leaves were found in plants treated with Fusarium incarnatum followed by Aspergillus aculeatus, Penicillium species and Fusarium javanicum. Only these fungal inoculations i.e. Penicillium species, Penicillium cyclopium, Aspergillus flavus have shown the highest no of leaf area as compared to uninoculated control.

Table 1. Growth performance of Gmelina arborea at transplantation stage and inoculated condition.

\begin{tabular}{|c|c|c|c|c|c|c|c|c|c|}
\hline \multirow{3}{*}{ Treatments } & \multicolumn{9}{|c|}{ Growth Parameters } \\
\hline & \multirow{2}{*}{$\begin{array}{c}\text { Shoot } \\
\text { Height }(\mathrm{cm})\end{array}$} & \multirow{2}{*}{$\begin{array}{c}\text { Root } \\
\text { Length } \\
(\mathrm{cm})\end{array}$} & \multirow{2}{*}{$\begin{array}{c}\text { No. of } \\
\text { Branch }\end{array}$} & \multirow{2}{*}{$\begin{array}{l}\text { No. of } \\
\text { Leaves }\end{array}$} & \multirow{2}{*}{$\begin{array}{c}\text { Leaf Area } \\
\left(\mathrm{mm}^{2}\right)\end{array}$} & \multicolumn{2}{|c|}{ Initial Biomass (g) } & \multicolumn{2}{|c|}{ Dry Biomass (g) } \\
\hline & & & & & & Shoot & Root & Shoot & Root \\
\hline Contror & & $22.2 \pm 3.2$ & & 0 & J & .7 & 0 & .3 & \\
\hline Aspergil & & 9 & & & & & & & \\
\hline Fusarium & 63.0 & $27.2 \pm$ & $3+$ & .2 & .9 & $50.9 \pm 5.2$ & 39.4 & 7.3 & 5.7 \\
\hline Aspergillu & 57.2 & $22.2 \pm 3.9$ & $2 \pm 1$ & 46.8 & $8107.0 \pm 8$ & $31.8 \pm 17.2$ & $26.7=$ & 3.2 & 3.4 \\
\hline Aspergillu & 61.3 & $26.3 \pm 6.6$ & $2 \pm 1.7$ & 3.0 & 5727.4 & $43.8 \pm 13.1$ & 25.2 & 5.0 & 3.8 \\
\hline Penicilliu & 70.7 & $27.5 \pm 4.2$ & $2 \pm 1$ & 52.3 & $1995.8 \pm 1321.9$ & $50.7 \pm 6.9$ & $49.7 \pm 11.0$ & $21.6 \pm 5.5$ & $20.2 \pm 6.5$ \\
\hline Alternaric & 46.5 & $29.8 \pm 4.7$ & $1 \pm 1.3$ & 1.9 & $4255.8 \pm 7$ & $22.0 \pm 5.1$ & $17.2 \pm 4.4$ & $10.9 \pm 3.2$ & $7.0 \pm 1.5$ \\
\hline Penicillium & $54.7 \pm 6.2$ & $31.2 \pm 2.9$ & $2 \pm 0.6$ & $42.5 \pm 11.5$ & $4469.4 \pm 185.7$ & $33.2 \pm 10.1$ & $32.2 \pm 9.3$ & $15.0 \pm 5.0$ & $12.4 \pm 4.6$ \\
\hline Fusarium & $52.2 \pm 1.1$ & $33.2 \pm 3.1$ & & $48.8 \pm 4.8$ & $4714.8 \pm 96.7$ & $37.1 \pm 8.0$ & $30.3 \pm 3.8$ & $19.3 \pm 2.4$ & $15.2 \pm 2.3$ \\
\hline Penicillium cyclopium & $63.0 \pm 3.7$ & $25.3 \pm 2.8$ & $3 \pm 1.0$ & $42.2 \pm 10.1$ & $15982.6 \pm 699.0$ & $43.8 \pm 4.5$ & $33.9 \pm 7.9$ & $19.3 \pm 3.7$ & $13.9 \pm 1.7$ \\
\hline Aspergillus flavus & $75.7 \pm 12.5$ & $28.7 \pm 2.4$ & $2 \pm 0.8$ & $36.2 \pm 7.6$ & $14228.0 \pm 923.0$ & $59.1 \pm 6.0$ & $38.0 \pm 6.2$ & $23.8 \pm 4.3$ & $16.9 \pm 1.4$ \\
\hline
\end{tabular}

Note: RGR= Relative Growth Rate; QI= Quality Index; NAR= Net Assimilation Rate; RSR= Root Shoot Ratio; LAR= Leaf Area Ratio.

In general, biomass in seedlings was higher under inoculated conditions as compared to control. Seedlings exhibited maximum biomass production when inoculated with fungal strains Fusarium incarnatum, Penicillium species, Penicillium cyclopium, Aspergillus flavus. Mean Biomass (fresh and Dry) measured after four months indicated the maximum increment in growth of plants inoculated with this fungi. It is apparent that, in the term of biomass, the seedlings inoculated with different fungi showed a higher production and superiority over control. Fusarium incarnatum, Penicillium species, Penicillium cyclopium, Aspergillus flavus inoculated plants attained maximum biomass with respect to control. Except for Aspergillus ellipticus, almost all other inoculants resulted increased in biomass in comparison to control. Relative growth rate (RGR) was also changed due to the enhancement in dry biomass, stem height and leaf area in transplanted conditions (Table 2). However, transplanted seedlings of Fusarium incarnatum, Penicillium species, and Aspergillus flavus showed higher RGR as well as Net assimilation rate. Growth analysis revealed that NAR (net assimilation rate), and LAR (leaf area ratio) accounted for the differences in RGR (relative growth rate) in the treatments. Data recorded for the quality index of Gmelina arborea Roxb. grown with selected fungal isolates in non transplanted and transplanted conditions showed better quality and comparatively more growth than the un-inoculated control. Application of 
selected fungal cultures resulted in an increase of biomass as compared to control, which leads to the successful establishment of Gmelina arborea.

Table 2. Physiological growth performance of Gmelina arborea under transplanted and inoculated condition.

\begin{tabular}{|c|c|c|c|c|c|c|}
\hline Treatments & $\begin{array}{c}\text { Wet RGR } \\
\left(d^{-1}\right)\end{array}$ & $\begin{array}{c}\text { Dry RGR } \\
\left(d^{-1}\right)\end{array}$ & $\begin{array}{c}\text { NAR } \\
\left(\mathrm{g} \cdot \mathrm{m}^{-2} \cdot \mathrm{d}^{-1}\right)\end{array}$ & $\begin{array}{c}\text { LAR } \\
\left(\mathrm{m}^{2} \cdot \mathrm{g}^{-1}\right)\end{array}$ & QI & RSR \\
\hline Control & 0.161 & 0.107 & 0.30 & 0.657 & 0.402 & 0.377 \\
\hline Aspergillus ellipticus & 0.030 & 0.085 & 0.06 & 0.609 & 0.465 & 0.485 \\
\hline Fusarium incarnatum & 0.370 & 0.189 & 0.37 & 0.455 & 0.617 & 0.432 \\
\hline Aspergillus aculeatus & 0.158 & 0.133 & 0.35 & 0.583 & 0.504 & 0.388 \\
\hline Aspergillus candidus & 0.291 & 0.160 & 0.04 & 0.436 & 0.520 & 0.429 \\
\hline Penicillium species & 0.368 & 0.177 & 1.15 & 0.640 & 0.587 & 0.392 \\
\hline Alternaria alternata & 0.049 & 0.058 & 0.07 & 0.587 & 0.371 & 0.641 \\
\hline Penicillium species & 0.174 & 0.104 & 0.10 & 0.480 & 0.491 & 0.571 \\
\hline Fusarium javanicum & 0.217 & 0.151 & 0.11 & 0.409 & 0.644 & 0.636 \\
\hline Penicillium cyclopium & 0.291 & 0.151 & 1.59 & 0.860 & 0.514 & 0.402 \\
\hline Aspergillus flavus & 0.461 & 0.202 & 1.77 & 0.667 & 0.530 & 0.379 \\
\hline
\end{tabular}

Note: RGR= Relative Growth Rate; QI= Quality Index; NAR= Net Assimilation Rate; RSR= Root Shoot Ratio; $\mathrm{LAR}=$ Leaf Area Ratio.

Application of liquid inoculants to seedlings was better than seed inoculation. It is recommended that seedlings raised in the nursery should be inoculated with liquid inoculants immediately or soon after germination (Odee et al. 2002). Organic and inorganic fertilizers are not only supply limited amount of nutrients to the plants but also needed in huge quantity. As Gmelina arborea is a forest grown plant, regular organic manure supplement is not possible. So it is an ideal choice to develop microbial consortia which help the plant root system to grow and absorb nutrients. It also improves the physiochemical and biological properties of soil. It has been reported that Gmelina arborea has weak establishment property but once it establishes in an environment, it grows quickly (Lamb 1968). In this regard, the supplementation of fungal cultures having phosphate solubilising potential to the transplanted seedlings may be the better option to overcome the transplantation and establishment problems. This process can also be applied to another forestry plant, those who has weak establishment property.

\section{ACKNOWLEDGMENT}

We are thankful for the financial support obtained from Forest and Environment Department, Govt. of Odisha under State Plan Project 2015-16.

\section{REFERENCES}

Barua A, Gupta SD, Mridha AU, Bhuiyan MK, Menon S, Mohan V \& Krishnakumar N (2010) Effect of arbuscular mycorrhizal fungi on growth of Gmelina arborea in arsenic contaminated soil. Journal of Forestry Research 21(4): 423-432.

Basak UC, Gupta N, Rautaray S \& Das P (2004) Effects of salinity on the growth of mangrove seedlings. Journal of Tropical Forest Science 16: 437-439.

Dash S, Mohapatra AK \& Gupta N (2013) Growth response of Dalbergia sissoo Roxb. to mineral solubilizing bacteria and fungi in nursery conditions. Tropical Ecology 54(1): 09-115.

Dhar PP \& Mridha MAU (2012) Arbuscular mycorrhiza associations in different forest tree species of Hazaikhil forest of Chittagong, Bangladesh. Journal of Forestry Research 23(1): 115-122.

Dickson AA, Leaf L\& Hosner JF (1960) Quality appraisal of white spruce and white pine seedling stock in nurseries. Forestry Chronicle 36: 10-13.

Lamb AFA (1968) Fast growing timber trees of the low land Tropics, Vol. 1. Commonwealth Forestry Institute, Oxford, UK.

Leopold AC \& Kriedemann PE (1975) Plant Growth and Development. McGraw-Hill Book Co., New York.

Manoharachary C, Sridhar K, Singh RA, Adholeya A, Rawat S \& Johri BN (2005) Fungal biodiversity, distribution, conservation and prospecting of fungi from India. Current Science 89(1): 59-70.

Mehrvarz S \& Chaichi MR (2008) Effect of phosphate solubilizing microorganisms and phosphorus chemical fertilizer on forage and grain quality of barley (Hordeum vulgare L.). Journal of Agriculture and Environment Science 3(6): 855-860. 
Odee DW, Indieka SA \& Lesueur D (2002) Evaluation of inoculation procedures for Calliandra calothyrsus Meisn. grown in tree nurseries. Biology and Fertility of Soil 36(2): 124-128.

Orwa C, Mutua A, Kindt R, Jamnadass R, Anthony S (2009) Agroforestry database: A tree reference and selection guide version 4.0. Available from: http://www.worldagroforestry.org (accessed: 10 Dec. 2016).

Pandey A, Das N, Kumar B, Rinu K \& Trivedi P (2008) Phosphate solubilization by Penicillium spp. Isolated form soil samples of Indian Himalayan Region. World Journal Microbiology Biotechnology 24: 97-102.

Pascual JA, Garcia C, Hernandez T\& Ayuso M (1997) Changes in the microbial activity of an arid soil amended with urban organic wastes. Biology and Fertility of Soils 24: 429-434.

Patil MG, Sayyed RZ, Chaudhari AB \& Chincholkar SB (2002) Phosphate solubilizing microbes: a potential bioinoculant for efficient use of phosphate fertilizers. In: Bioinoculants for sustainable agriculture and forestry. Scientific Publishers, pp. 107-118.

Reis MR, Silva AA, Guimaraes AA, Costa MD, Massenssini AM \& Ferreira EA (2008) Action of herbicides on inorganic phosphate solubilizing microorganisms in sugarcane rhizospheric soil. Planta Daninha 26(2): 333-341.

Richa G, Khosla B \& Reddy MS (2007) Improvement of Maize plant growth by phosphate solubilizing fungi in rock phosphate amended soil. World Journal Agriculture Science 3: 481-484.

Sahgal M, Sharma A, Johri BN, Prakash A (2004) Selection of growth promontory Rhizobia for Dalbergia sissoo from diverse soil ecosystems of India. Symbiosis 36(1): 83-96.

Sturmann M, Bergmann, Zech W (1994) Mineral nutrition, soil factors and growth rates of Gmelina arborea plantations in the humid lowlands of Northern Costa Rica. Forest Ecology and Management 70:135-145.

Tewari P, Saxena AK \& Rao OP (2006) Effect of sodicity and salinity on seedling growth of two early successional agro forestry tree species. Tropical Ecology 47: 125-132.

Thatoi HN, Sahu S, Mishra AK, Padhi GS (1993). Comparative effect on VAM inoculation on growth, nodulation and Rhizobium population of Subabul (Leucaena leucocephala Lam. de Wit.) grown in iron mine waste soil. The Indian Forester 119: 481-489.

Yadav J, Verma JP, Tiwari KN (2011) Plant growth promoting activities of fungi and their effect on Chickpea plant growth. Asian Journal of Biological Science 4(3): 291-299. 